\title{
Poor Community Profile Based on Local Future from Matraman Cultural Ethnic
}

\author{
Mulyanto \\ Lecturer at Faculty of Agriculture \\ Pembangunan Nasional University (UPN) East Java \\ Surabaya, Indonesia \\ mulyanto@upnjatim.ac.id \\ Suprapti Supardi \\ Lecturer at Faculty of Agriculture \\ Sebelas Maret University (UNS) Surakarta \\ Surakarta, Indonesia \\ supraptisupardi@gmail.com
}

\author{
Endang Siti Rahayu \\ Postgraduate student of Sebelas Maret University (UNS) \\ Surakarta) \\ Sebelas Maret University (UNS) Surakarta \\ Surakarta, Indonesia \\ buendanguns@gmail.com \\ Syarif Imam Hidayat \\ Lecturer at Faculty of Agriculture \\ Pembangunan Nasional University (UPN) East Java \\ Surabaya, Indonesia \\ syarifimamhidayat@yahoo.com
}

\begin{abstract}
National data on the number of poor people has declined. However, it still remains vulnerable. The existence of economic turmoil, such as crop failure and rising fuel prices can quickly add to the poverty rate of farmers. This research question relies on the fact that there are still many empirical studies that deal with poverty seen from local wisdom. Therefore, the researchers tried to find a solution (way out) of how to alleviate poverty in society viewed from the culture and its causes. Meanwhile the research design was aimed at and focused on the Mataraman cultural ethnic in Pacitan Regency, based on investigative investigators. The purpose was to identify the poor based on local wisdom from the Mataraman cultural ethnic. This research used a qualitative approach (qualitative research) with a purposive method to explore and understand the meaning of poverty by a number of individuals or groups of people considered to come from social or humanitarian problems, and even still many other local wisdom activities that are very helpful for the poor, for example: Ciprotan, Lungkangan, Resik Desa, Tandur Panen, Genggongan (Tayuban), Ringgit (Wayangan), Sambatan, Bawonan, Bedah Bumi, the above activities produce values of mutual cooperation between the poor and capable people in their economic status, as well as the case, at the time of planting and harvesting, and when there are members of the village community building a house, it can be ascertained that the workforce is a member of the community and is not paid, but for consumption those who work from someone has an interest, in addition to cheaper costs, the house finishes faster.

Keywords-local wisdom, mataraman culture, poor people
\end{abstract}

\section{INTRODUCTION}

Poor is a multidimensional problem that is in the midst of society because it is related to the lack of ability in social, economic, political and socio-cultural access, as well as participation in society. It can be seen that there is a growing number of poor people from year to year in a district / region, so that programs planned to reduce poverty need a review, which needs to get attention and understanding the characteristics of poverty in each region or region.

Therefore, inclusive growth can play an important role in reducing poverty. So many ways have been done to reduce poverty, its existence is a separate force for national development. Nevertheless, various empirical findings explicitly imply the conditions of poverty of farmers, not the only one caused by limited land [1]; [2]; [3]; [4]; mentions include malpractice of development due to wrong economic policy formulations, low productivity, limited policies in the development of poor infrastructure production technology due to isolated and low areas [5] level of education, health and investment. The poor in another focus can be explained through the capability approach proposed by Amartya Sen [6] in his book entitled "Development as Freedom". According to Sen, poverty related to freedom of choice of the poor does not have freedom of choice at all because of deprivation capability. Capability refers to two cases, namely ability to do (ability to do) and ability to be (ability to be). Besides that capability is also able to influence social and economic changes, the advantages and disadvantages arising from the conditions of the surrounding natural environment, the condition of the community and the physical character of a person will influence the individual in his efforts to achieve well-being. Amartya Sen suggests that the existing rules will affect each individual in activity. Individuals live with different environments with others who also have different rules. Ironically, the existence of actual development can be threaten the elimination of traditions and cultural heritage [7]. If the culture of life must be sacrificed to overcome poverty, it is necessary to have the opportunity to decide on direct involvement with the development process. Real conflicts that often occur are 1) the basic value that the community is allowed to decide freely on the development that they want, or 2) the pressure of development without adhering to and upholding the local culture. Furthermore, this friction shows the cultural reaction of society, shown by rejecting all forms of update, innovation and other new ideas which are considered to threaten their survival [8].

Integrating the behavior of certain community groups and ways of thinking about poverty was stated by Ningaye [1]; the results of his research explain the differences in observing the dimensions of poverty with culture, namely the culture influencing poverty both differences in perception and differences in the determinants of poverty. Maintaining cultural values for an individual, poverty can be reduced [9].

Ethnic groups are social groups with each member having the same origin, same historical and fate background, and having one or several unique cultural and solidarity characteristics [1]. 
Referring to the East Java cultural mapping [10], dividing the cultural area in East Java consists of the cultures of Mataraman, Panaragan, Samin, Arek, Tengger, Pandalungan, Osing, Madura Island, Madura Bawean and Madura Kangean. Historically, some East Java residents have a close cultural bond with the mataraman kingdom. Administratively, government or geocultural, the distribution of Mataraman culture which is identified with the Pacitan region which is included in the poverty pockets. Mataraman culture has characteristics that are polite, patient, paternalistic, and aristocratic. This research describes the geographical area of Pacitan district which is categorized as poor in East Java and which represents the Mataraman culture. Pacitan Regency is located in the southwestern tip of East Java province, on the south coast of Java Island and borders the Central Java Province and the Special Region of Yogyakarta, so the mataraman cultural influence is very strong, the area of $1,389,871 \mathrm{Km}$ is mostly in the form of hills, which is $\pm 85 \%$, small mountains \pm 300 pieces, which are scattered in the region of Pacitan Regency and steep ravines which are included in a row of thousand mountains, which stretch along the south of the island of Java, while the rest are lowland, topographic aspects of the landscape vary with slope of $0-52 \%$ [11].

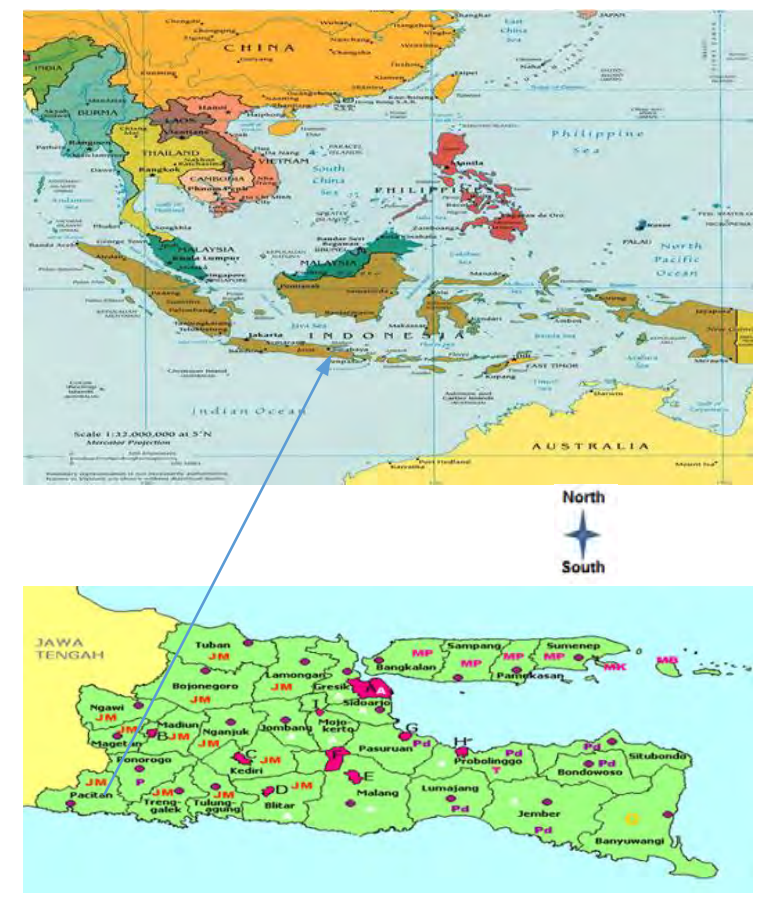

Figure 1. Map of Research Location

The administrative area consists of 12 subdistricts, 5 villages and 166 villages, with geographical locations between $110^{\circ} 55^{\prime}-111^{\circ} 25^{\prime}$ East Longitude and $7^{\circ} 55^{\prime}-8^{\circ} 17^{\prime}$ South Latitude.

Administrative Boundaries:

1. East Side

2. South Side
: Trenggalek Regency
: Indonesia Ocean
: Ponorogo Regency (East java) and Wonogiri Regency (Centre java)

3. Western side

4. North side
Studying culture is a multicultural and inter-ethnic cultural hybridization. This is due to the many different types of cultures that blend together which are referred to as Mataraman culture [1]. Hybridization between the two ethnicities produces two major groups in its distribution between East Java and Centre Java.

\section{PURPOSE OF RESEARCH}

The purpose of this research is; to describe the profile of the poor according to the Cultural approach where should emphasize alleviate poverty and photograph the culture of poverty actors themselves, in the Mataraman ethnic culture in Pacitan Regency

\section{RESULTS AND DISCUSSION}

The data were collected by using a qualitative approach, including primary data and secondary data, interviews using several instruments namely field notes and audio recording devices, cameras, and other instruments.

\section{A. Deep Interview}

Direct interviews with informants are carried out to obtain an in-depth understanding, where researchers hold direct, verbal or face-to-face contact with data sources, such as informants and other parties, both in actual (formal) situations and in deliberate situations. research needs (informal).

\section{B. Documentation}

Performed in the form of taking pictures, either in the form of photos or other things to support the visualization of data that has been obtained from various data collection techniques, the FGD in this research is needed when researchers want to uncover harmony between local apostasy and existing government representatives in the district, village head, Agricultural Extension, Community Leaders, and farmer groups.

\section{RESULTS AND DISCUSSION}

\section{A. Mataraman Demographic Profile}

According to the results of the 2014 population registration, the population of Pacitan Regency was 540,881 inhabitants. The composition of the population by sex consisted of men of 264,112 people (48.83 percent) and women of 276,769 people ( 51.17 percent) with a sex ratio of 95.43 percent. This means that every 100 female population is 95-96 male population. The population density of Pacitan Regency in 2014 was 431 people / km2. The highest population density is Pacitan Subdistrict as the district capital which reaches.

993 Million / Km2, this is very far compared to the population density of other sub-districts which only ranges between 241-538 Million / Km2. based on the composition of its age, the population of Pacitan Regency as many as 402,271 souls are in the productive age of 15-64 years old or 67.10 percent. This study presents Mataraman Demographic Profile, Mataraman ethnic culture represented from Pacitan Regency. In the study it was found that the majority of respondents had dependents of two to three children or families who participated in the house who were still dependent. As well as all respondents have health insurance coverage (Jamkesmas), only a small percentage do not have 
Jamkesmas, on average within the respondent's family, there is only one person who becomes the backbone of family life. The average respondent of Mataraman ethnic culture works as a farm laborer, this is because they only have a narrow land (small farmers) especially in the Mataraman ethnic culture whose lives near the forest are often disturbed by wild animals, which are also protected by law to avoid extinction, to meet the needs of life, in addition to farm labor, respondents also work to break rocks.

\section{B. Profile of Mataraman Cultrul Custom}

Culture is a mirror of society that cannot be separated from the behavior of the supporting community. As for the activities as follows: the first activity, when there are members of the village community building a house, it can be ascertained that the workforce is a member of the community, but for the consumption of laborers who have a need, in addition to cheaper costs, the house is also faster to finish, because the workforce is quite a lot and can help those who are poor to help the cost of eating from their families. Attitudes and configurations that exist in the behavior of certain communities can be understood by understanding the wisdom in certain areas. can be seen in the table 1 .

Table 1. Local Wisdom List

\begin{tabular}{|c|c|c|c|c|c|}
\hline No & Location & $\begin{array}{c}\text { Activity } \\
\text { Name }\end{array}$ & Time & Activity & $\underset{n}{\text { Informatio }}$ \\
\hline 1 & $\begin{array}{l}\text { Kasihan } \\
\text { Village } \\
\text { Kec. } \\
\text { Tegal } \\
\text { ombo } \\
\text { Kab. } \\
\text { Pacitan }\end{array}$ & Ciprotan & $\begin{array}{l}\text { Selo } \\
\text { /Lungkan } \\
\mathrm{g} \text { (after } \\
\text { syawal), } \\
\text { first legi } \\
\text { wednesda } \\
\text { y, before } \\
\text { Wayang } \\
\text { kulit }\end{array}$ & $\begin{array}{l}\text { - } \\
\text { Kenduren } \\
\text { (in } \\
\text { Javanese } \\
\text { Banca'an) } \\
\text { continued } \\
\text { tari-tarian } \\
\text { (sendratar } \\
\text { i) Endang } \\
\text { loro } \\
\text { Tompe }\end{array}$ & $\begin{array}{l}\text { For respect } \\
\text { of Dewi } \\
\text { Sekartaji } \\
\text { and Panji } \\
\text { Asmoro } \\
\text { Bangun }\end{array}$ \\
\hline 2 & & $\begin{array}{l}\text { Lungkan } \\
\text { gan }\end{array}$ & $\begin{array}{l}\text { After } \\
\text { Ciprotan } \\
\text { event }\end{array}$ & $\begin{array}{l}\text {-Wayang } \\
\text { kulit } \\
\text { - clean } \\
\text { up } \\
\text { The } \\
\text { water } \\
\text { sources } \\
\text { that } \\
\text { people in } \\
\text { kasihan } \\
\text { village } \\
\text { used }\end{array}$ & $\begin{array}{l}\text { Costs from } \\
\text { the } \\
\text { community }\end{array}$ \\
\hline 3 & & $\begin{array}{l}\text { Resik } \\
\text { Desa }\end{array}$ & $\begin{array}{l}\text { - Before } \\
\text { fasting } \\
\text { month } \\
\text { - before Id } \\
\text { mubarok }\end{array}$ & $\begin{array}{l}\text { Clean up } \\
\text { village } \\
\text { street in } \\
\text { gotong } \\
\text { royong }\end{array}$ & $\begin{array}{l}\text { Costs from } \\
\text { the } \\
\text { community }\end{array}$ \\
\hline $\begin{array}{l}4 \\
.\end{array}$ & & $\begin{array}{l}\text { Tandur } \\
\text { Panen }\end{array}$ & $\begin{array}{l}\text { Harvest of } \\
\text { rice }\end{array}$ & $\begin{array}{l}\text {-villagers } \\
\text { of kasihan } \\
\text { that work } \\
\text { in other } \\
\text { village } \\
\text { get home } \\
\text { to their } \\
\text { village to } \\
\text { join } \\
\text { planting } \\
\text { of rice } \\
\text { - join the } \\
\text { harvest of } \\
\text { rice }\end{array}$ & $\begin{array}{l}\text { Costs from } \\
\text { those who } \\
\text { have } \\
\text { activities }\end{array}$ \\
\hline
\end{tabular}

a. Source: Kasihan Village, Kec. Tegalombo, Kab. Pacitan

\begin{tabular}{|c|c|c|c|c|c|}
\hline No & $\begin{array}{c}\text { Locatio } \\
\text { n }\end{array}$ & $\begin{array}{c}\text { Activity } \\
\text { Name }\end{array}$ & Time & Activity & $\begin{array}{c}\text { Informat } \\
\text { ion }\end{array}$ \\
\hline 1 & $\begin{array}{l}\text { Sido } \\
\text { Mulyo } \\
\text { Village } \\
\text { Kec. } \\
\text { Ngadiroj } \\
\text { o, Kab. } \\
\text { Pacitan }\end{array}$ & $\begin{array}{l}\text { Genggong } \\
\text { an } \\
\text { (Tayuban) }\end{array}$ & $\begin{array}{l}\text { Lungka } \\
n g \\
\text { (After } \\
\text { Syawal) } \\
\text {, } \\
\text { Tuesday } \\
\text { of } \\
\text { Kliwon }\end{array}$ & $\begin{array}{l}\text { There are } \\
\text { dancers } \\
\text { accompani } \\
\text { ed by } \\
\text { musical } \\
\text { instrument } \\
\text { s } \\
\text { (gamelan), } \\
\text { sometimes } \\
\text { there are } \\
\text { people } \\
\text { who dance }\end{array}$ & $\begin{array}{l}\text { Costs } \\
\text { from the } \\
\text { communi } \\
\text { ty }\end{array}$ \\
\hline 2 & & $\begin{array}{l}\text { Ringgit } \\
\text { (Wayanga } \\
\text { n) }\end{array}$ & $\begin{array}{l}\text { Once in } \\
3 \text { year, } \\
\text { in big } \\
\text { month }\end{array}$ & $\begin{array}{l}\text { The } \\
\text { wayang is } \\
\text { preceded } \\
\text { by } \\
\text { recitation }\end{array}$ & $\begin{array}{l}\text { Costs } \\
\text { from the } \\
\text { communi } \\
\text { ty }\end{array}$ \\
\hline
\end{tabular}

b. Source: Sidomulyo Village, Kec. Ngadirojo, Kab. Pacitan

\begin{tabular}{|c|c|c|c|c|c|}
\hline No & Location & Activity Name & Time & Activity & Information \\
\hline 1. & $\begin{array}{l}\text { Sukorejo } \\
\text { village, } \\
\text { Kec. } \\
\text { Sudimoro, } \\
\text { Kab. } \\
\text { Pacitan }\end{array}$ & -Sambatan & $\begin{array}{l}\text { Building } \\
\text { a house }\end{array}$ & $\begin{array}{l}\text { If there are } \\
\text { people } \\
\text { build } \\
\text { houses, } \\
\text { then other } \\
\text { people } \\
\text { help as the } \\
\text { volunteers } \\
\text { who do not } \\
\text { get salary } \\
\text { (gotong } \\
\text { royong) }\end{array}$ & $\begin{array}{l}\text { The cost of } \\
\text { building a } \\
\text { house, } \\
\text { people help } \\
\text { workers. }\end{array}$ \\
\hline 2. & & -Bawonan & $\begin{array}{l}\text { When } \\
\text { planting } \\
\text { rice and } \\
\text { harvesting } \\
\text { rice }\end{array}$ & $\begin{array}{l}\text { At the time } \\
\text { of planting } \\
\text { and at } \\
\text { harvest, } \\
\text { there are } \\
\text { some } \\
\text { people } \\
\text { who are } \\
\text { asked to } \\
\text { help }\end{array}$ & $\begin{array}{l}\text { The cost of } \\
\text { the people } \\
\text { who own the } \\
\text { land, by the } \\
\text { Bawon } \\
\text { method, } \\
\text { which helps } \\
\text { to plant and } \\
\text { harvest paid } \\
\text { rice, with } \\
\text { the harvest }\end{array}$ \\
\hline 3. & & $\begin{array}{l}\text { Bedah } \\
\text { Bumi }\end{array}$ & $\begin{array}{l}\text { If there } \\
\text { are } \\
\text { villagers } \\
\text { who die }\end{array}$ & $\begin{array}{l}\text { Funeral } \\
\text { work } \\
\text { division, } \\
\text { The } \\
\text { district } \\
\text { people } \\
\text { whose one } \\
\text { of them } \\
\text { died, got } \\
\text { their jobs } \\
\text { taking care } \\
\text { of their } \\
\text { bodies } \\
\text { until they } \\
\text { were } \\
\text { buried, } \\
\text { while } \\
\text { other } \\
\text { helped dig } \\
\text { up burial } \\
\text { pits. }\end{array}$ & \\
\hline
\end{tabular}




\section{Mataraman Poor People}

The main capital in the planning of poverty alleviation programs is how the poor see themselves. This research found several problems that relate to the poor to the conditions inherent in society, where the perspective of the poor towards their conditions reflects the "character of social poverty". become some parts like why they are poor? how to measure poverty, how do they get out of poverty? What programs are expected to get them out of poverty? the following is an explanation of the perspective of the poor; Several informants in the FGD in Mataraman cultural ethnic felt poor because the condition of their house was small, ugly and not made of brick, but from bamboo (gedek), with a dirt floor, poverty measurement was also based on their income that could not meet the needs of the family they, they also feel poor because they don't have a permanent job which can be a regular source of income. The inability to continue higher education or to send their children well is also one reason why they feel poor. In Pacitan District where the research area is rural, they feel poor because they only have small land for agriculture (small farmers), or even have no land and only farm laborers. Moreover, in Pacitan they feel desperate to work on their own land often attacked by wild animals which is precisely, the animal is protected by law so as not to be killed by humans.

\section{Poor Causes of the Mataraman Community}

\section{Poor Factor}

Identify the factors that cause a person to become poor as followed: Poverty is the first element that makes poor people. The poverty is the most dominant factor among other factors. Since the poverty can cause a person to be physically weak due to lack of food, malnutrition, susceptible to disease attacks, susceptible to emergencies or urgent circumstances because they do not have wealth, and someone becomes helpless because of loss of welfare and has a very low position in East Java, Pacitan Regency is the 5th poorest area (16.66 percent) according to the data of the Percentage of Poor Population in East Java district / city, the source of East Java in the BPS Figures, 2015, so that the respondents are all included in the poor category.

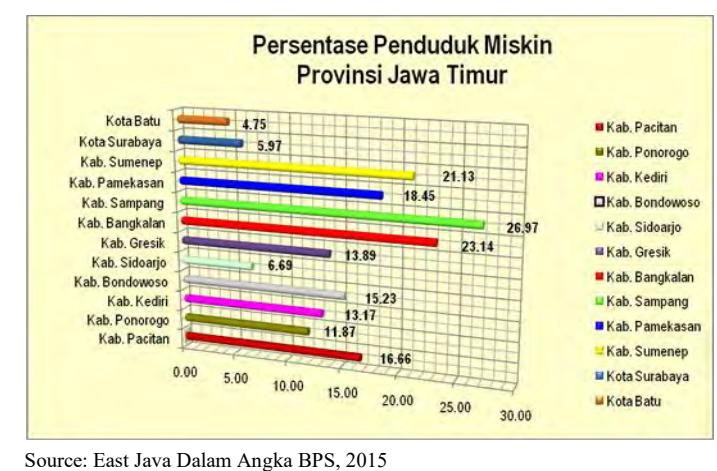

Figure 2. Percentage of Poor Population in East Java District/City

\section{Behavior Factor}

Among the respondents there were stories, that they had started a business, sold fruit and pulses. However, they were rare and rotten, and many pulses that were used by themselves while those that sold little and were not neatly arranged in their finances who cannot stop smoking.

\section{Skill Factor}

The skill factor greatly influenced the emergence of poverty, the respondents said that, had been influenced by someone to go abroad, but because they did not have good skills at all. Then the respondents joined the illegal labor group, one day caught and rewarded with a 6-month confinement, so returning home did not bring any results at all, even grew poorer.

\section{Heritage Factor}

The inheritance of a house or land from parents to their children, some of which may not be sold to someone other than education, so that the family must own and occupy the family of his heir, one of the respondents said that he and his family did not allow to work in a place far from his village because he has to occupy a house from the family that is inherited from his parents, where the house cannot be sold by his parents or heirs, and is the center of gathering of relatives (punden), especially on holidays or Lebaran, especially if their parents are still alive.

\section{Education Factor}

The factor of education is the main factor of poverty that conducted to this research, where the informants, thinking that for example higher education can be achieved first, surely the situation would be different, it will be better and not poor as they are now, they think their children must be highly educated, but in Pacitan district was found in Bubakan village, Tulakan subdistrict, who thought that his child had enough junior high school, continued to work, to make money, could help parents, so that many of the Bubakan village children who after graduating from junior high school would no longer continue to pursue higher education in the interview with respondents who stated as follows: "... Lare-lare mriki sedoyo nggih ngaten sedoyo ..." (... "the children here are all like this ..."), the respondents said that most of the village children were bubakan, after junior high school find work right away. "... my son is still interested in graduating from junior high school ..." while in Ngile village is still in Tulakan sub-district, the community wants their children to go to college, but outside Pacitan. The following presentation presents the Poverty Demographic Profile Mataraman ethnic farmers are a productive group of poor farmers. Most of the respondents were educated up to elementary school, although there were also gapoktan with undergraduate degrees as well as Mataraman culture which passed 86.00 percent elementary school.

\section{CONCLUSION}

From the research with the title: Profile of the poor Based on local wisdom from Mataraman cultural ethic, it can be concluded: that the profile of the poor from the Mataraman ethnic group in the district, proved to be still in existence: Ciprotan, Lungkangan, Resik Desa, Tandur Panen, Genggongan (Tayuban), Ringgit (Wayangan), Sambat, when a member of the village community builds a house, it can be ascertained that the workforce is from non-poor community members at low cost, but for their daily consumption those who work are provided from those who have a house or who build the house, in addition to cheaper costs, the house is also faster to finish. Bawonan, The cost of the people who own the land, by means of Bawon, which 
helps to plant and harvest paid rice, with the results of harvesting and earth surgery, distribution of funeral work, district people whose one of them die, getting work to take care of their bodies until buried, while other district people help dig a burial hole. Mataraman cultural ethnic in Pacitan Regency, still has values of cooperation between the poor and capable people in their economic status.

\section{ACKNOWLEDGMENT}

I am deeply indebted to my supervisor, Professor Endang Siti Rahayu. Head of Department of Sebelas Maret University (UNS) Surakarta, for warm support, inspiration and thoughtful guidance.

\section{REFERENCES}

[1] Minten, Bart and Christopher B. Barrett. 2008. "Agricultural Technology, Productivity, and Poverty in Madagascar Agricultural Technology, Productivity, and Poverty in Madagascar.” 36(5):1-45. Retrieved (https://doi.org/10.1016/j.worlddev.2007.05.004).

Ningaye, Paul. 2011. "Ethno-Cultural Diversity and Multidimensional Poverty Differential in Cameroon.” International Journal of Development Issues 10(2):123-40.

[2] Christiaensen, Lionel Demery, Jesper Kuhl, 2011, The (evolving) role of agriculture in poverty reduction-An empirical perspective, Journal of Development Economics 96 (2011) 239-254.

[3] Abro, Zewdu Ayalew and Alemu Hanjra, Munir A. 2014. "Policies for Agricultural Productivity Growth and Poverty Reduction in Rural Ethiopia." World Development 59:461-74. Retrieved (https://doi.org/10.1016/j.worlddev.2014.01.033)

[4] Medina G, Camila A, Evandro N, Javier G, Benno P. 2015. Development Conditions for FamilyFarming: Lessons From Brazil, World Development Vol. 74, pp. 386-396, 2015.

[5] Adair, T., J. F. Pardosi, C. Rao, S. Kosen, and I. U. Tarigan. 2012. "Access to Health Services and Early Age Mortality in Ende, Indonesia." Indian Journal of Pediatrics 79(5):612-18. Retrieved (https://scholar.google.com/)

[6] Amartya Sen , 1999, Development as Freedom. OUP, Oxford

[7] Maraña, Maider. 2010. "Culture and Development Table O F Contents." UNESCO Etxea 1:30. Retrieved (www.unescoetxae.org).

[8] Syawaluddin. 2015. "SELF-CONCEPT OF CHILDREN REVIEWED FROM SEVERAL GUYS IN PADI CITY PADANG." Journal of Gender Studies 1(1):75-86. Retrieved (http://www.ejournal.iainbukittinggi.ac.id).

[9] Guiso. 2006. "Human Rights and Capabilities." Journal of Human Development 6(2):151-66. Retrieved (http://www.tandfonline.com/doi/abs/10.1080/14649880500120491 )

[10] Susanto dan Setya, 2008, Pemetaan Kebudayaan Provinsi Jawa Timur, Biro Mental Spritual Pemerintah Provinsi Jawa Timur

[11] Badan Pusat Statistik. (2015). Statistik Indonesia 2013. Katalog BPS (pp. 1-688). Jakarta: Badan Pusat Statistik. https://doi.org/10.1007/s13398-014-0173-7.2 